\title{
Resource-based Theory and Service-dominant Logic: A New Combined Approach to Revisit the Strategies of Cultural Firms in the Global Era
}

\author{
Valentina Della Corte ${ }^{1}$, Clelia Cascella ${ }^{2} \&$ Iris Savastano $^{1}$ \\ ${ }^{1}$ Department of Management, 'Federico II' University of Naples, Naples, Italy \\ 2 Department of Economics, 'Federico II' University of Naples, Naples, Italy \\ Correspondence: Valentina Della Corte, 'Federico II' University of Naples, Via Cinthia, Monte S. Angelo, 80126, \\ Naples, Italy. Tel: 39-81-675-370. E-mail: valentina.dellacorte@unina.it
}

\author{
Received: October 1, 2012 Accepted: October 29, 2012 Online Published: November 14, 2012 \\ doi:10.5539/ijms.v4n6p157 URL: http://dx.doi.org/10.5539/ijms.v4n6p157
}

\begin{abstract}
The aim of this article is to analyze cultural firms' evolution, in terms of strategic management, in a global era. As regards the methods, we propose a methodological approach based on the combination of Resource Based Theory and Service Dominant Logic, according to which "customers do not buy goods or services: they buy offerings which render services which create value". According to this perspective, cultural firms need to manage the strategic interaction between internal/external resources (territorial factors and firm specific resources) and internal/external networks (including customers and trade actors). In this process, the customer becomes a strategic resource: he/she is involved in cultural activities (i.e. edu-tainment) and becomes value co-producer and co-creator. In this optic, cultural activities have to be connected to the territory, in order to be real attractive factors, connected with local identity. This can be the new horizon for cultural firms to become competitive on the global market.
\end{abstract}

Keywords: cultural firms, strategic management, innovative approach, service-dominant logic, resource-based theory, co-creator, co-producer

\section{Introduction}

Cultural attractive factors are part of a very difficult scenario, in which the static cultural site, museum seems not to be attractive any longer. Therefore, the aim of our research is to analyze cultural firms' evolution, in terms of strategic management, in a global era. This requires new strategies, the applications of more managerial tools and practices and much more differentiated offers. Therefore, it is necessary to make an analysis of the context in order to study the evolution of the museum sector that, today, has no longer the only aim of maintaining and administering the patrimony, but also of increasing and enhancing it through the most appropriate policies. The museum is, in fact, a real firm in a wider system, intended to provide a plurality of functions, such as cultural activities and services of different kind (Bagdali, 1997). The service provided by museums has been changing over time, together with the evolution of objectives of such cultural organizations. The traditional core of the museum, its conservative function has in fact expanded, owing to the increasing and varying demand, characterized by deep changes in size and contents. Compared to the diagram in Fig. 1, the first two functions "conservative" and "exhibition" are due to basic services of the museum offer, while the third function (Solima, 1998, 1995) develops a series of activities that aim not only to a museum's enrichment, but also to an increase in profits (Baldassarre, 2009). This function grows out from the need to develop greater competitiveness against other competitors. In this paper, we focus specifically the study of Italian context. However, the proposed model can be applied to other settings. Looking at Italy as a country endowed with the majority of cultural resource in the world, museums are very numerous and often arise as sites for the preservation of artifacts found in archaeological sites of the surrounding area or as places to protect the culture of an area. For several years, however, the enhancement activity of the museum has been put in the middle of strategic management operations and the role of the user/consumer has changed, because he becomes the reference point and the final date for surviving and even becoming competitive. In particular, the situation has been changing when people have started to consider and appreciate the historical and artistic heritage, not just according to its intrinsic value, 
but also to the possible economic value. Between the $80 \mathrm{~s}$ and $90 \mathrm{~s}$, then, there was a change in the awareness that the economic resources necessary for the conservation and protection of cultural property could not be obtained simply on the basis of their ethical and aesthetical value of the assets. Therefore, in the eighties the foundations of marriage between cultural heritage and economy were laid, while the concept of profitability has crept into the political and cultural Italian museum just at the beginning of the nineties, when Ronchey, then Minister of Culture, introduced for the first time the "private logic" in the museums with the Italian Legislative Decree 433/1992 (published in Law 4 / 1993) which established, in the museums, "additional services fee" (library management, catering, cafeteria, etc.) in their management.

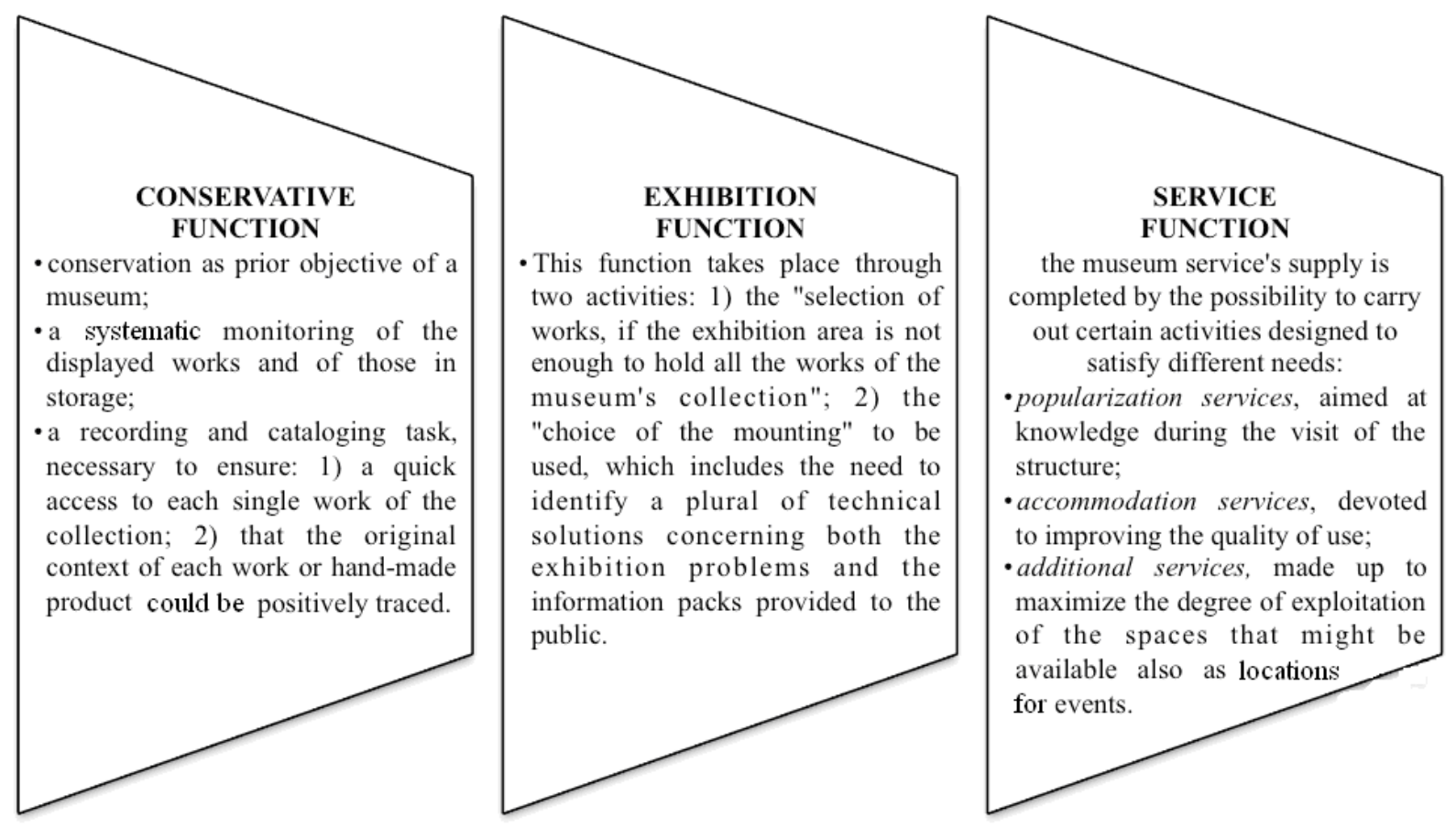

Figure 1. Characteristics of the main functions of a museum business

This trend to entrust the management of the museum to a private logic had its consecration by the entry into force of the Legislative Decree 42/2004 - Code of Cultural Heritage and Landscape. It requires organization not just in the management of ancillary services to cultural heritage, but in the direct management of the property in question (i.e. the "custody" or "concessions" procedures). In the Code of Cultural Heritage and Landscapes, the art. 115 provides for the possibility of granting to museums the management of all enhancement activities, including the teaching and educational initiatives, the organization of art exhibitions and of other cultural events. From here, many contributions have expanded the discourse up to the case of museums that turn themselves into events' locations. The success of the events in exclusive sites, in fact, varies according to their ability to evolve and present themselves differently in places and times in which they occur. This activity leads to the containment, and in some cases, to the exceeding of the problem of lack of funds through the activation of a strong managerial and economic culture. To preserve and increase their own competitive advantage, also cultural firms (museum, archeological sites, etc.) show the need to implement business schemes more and more closer to a managerial perspective, through which they can propose a much more differentiated offer. So cultural firms can achieve the following goals:

1) Attracting a major number of customers, offering a cultural experience, very innovative respect to the traditional business schemes;

2) Involving the customers in a process of value creation through events organized into the cultural firms and connected with the identity of the territory in which they are located. For example, we can imagine a contemporary dance of San Carlo ballet into the Madre Museum or a wine and gastronomic "tour" into the Mac with the cooperation of local community. 
Therefore, our research questions are:

1) The cultural firms (including museums) need to revisit and enlarge their offers, becoming more than artworks containers in a vision of customer as co-producer or (better) co-creators;

2) Events' organization can be considered a relevant factor in the overall cultural product offered by the museum and the museum itself can become a location for events;

3) To achieve this goal, cultural firms have to single out the resources and competences able to generate competitive advantage;

4) To win the challenge it is necessary to realize that living in a global word is an important variable in cultural firms' management.

To check the research hypotheses, our theoretical framework has to draw, at the same time, from Resource Based Theory (RBT - Barney, 1986, 1991, 2002, 2006) and from Service Dominant Logic (SDL - Vargo, 2004, 2006), that considers customers (Vargo\& Lush, 2004; 2008a; 2008b), employees and other actors as resource integrators. So, the value creation is conceived as process based on the interaction of complex networks of different actors (Vargo \& Lusch, 2004; Nicholls, 2010; 2011).

According to SDL perspective, the "value-in-use" (Grönroos, 2008; Payne et al., 2008; Vargo\&Lusch, 2004, 2008a, b) becomes a key concept. In this view the user is: 1) the customer as a primary actor during the process of value creation related to value-in-use; 2 ) the payer as a key subject during value-in-exchange and, finally 3 ) the buyer that can cover each of the underlined roles (Michel et al., 2008). In this context, SDL has to be integrated and supported by the RBT perspective. In fact, on one side, cultural firms must integrate the co-creation activities, through the development and the exploitation of internal resources and competences. On the other side, the interactions between service provider and customer require absorptive capacity (Cohen \&Levinthal, 1990; Zahra \& George, 2002) in order to understand customers' needs and acquire information in the process of value co-creation to after translate them in value offerings. In fact, successful firms must be able to develop the appropriate capabilities to co-opt customers' competences (Prahalad\&Ramanswuamy, 2000) and knowledge.

So, our combined approach can be synthesized as in fig. 2 .

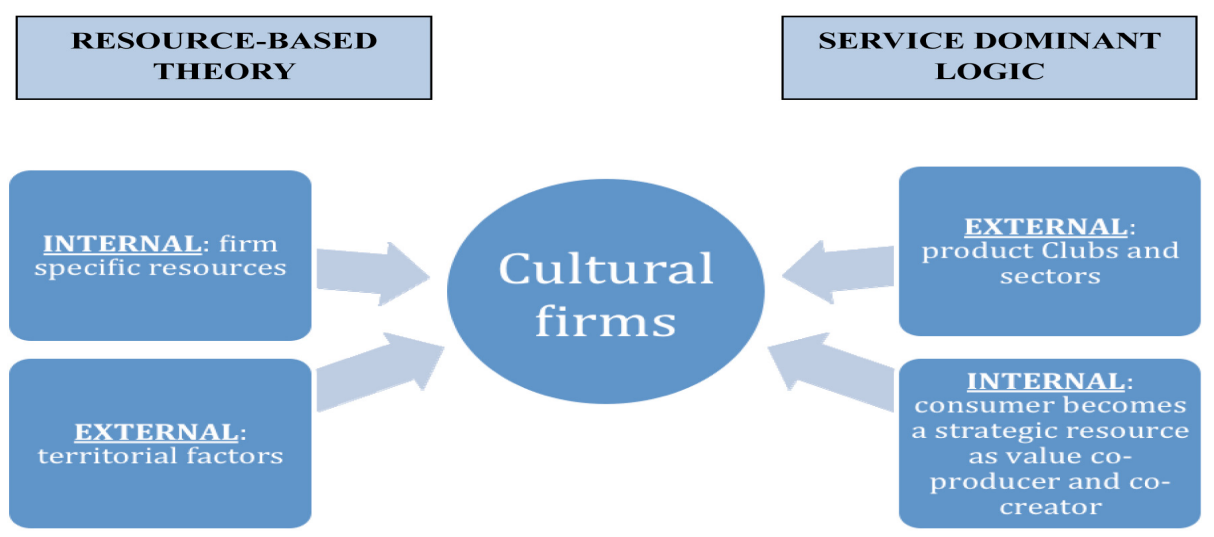

Figure 2. Theoretical framework based on a combined approach between resource-based theory and service-dominant logic

\section{The Proposed Theoretical Framework}

By combining RBT and SDL, we propose a new business model for cultural firms useful to develop much more differentiated offers. According to SDL perspective, customer's perception can change his/her usage of the product/service in an inherent process: innovation can be conceived as any change deriving from co-production and interactive processes, put forward by specific competences of different nature (Tax \& Stuart, 1997). To achieve this goal it needs to propose a very much differentiated cultural offer. So, in addition to traditional factors (art exhibitions, traditional visits at museum and heritage sites, etc.), cultural firms have to propose more innovative factors. The main aspects of innovation in cultural offers as schematized in figure 3. 


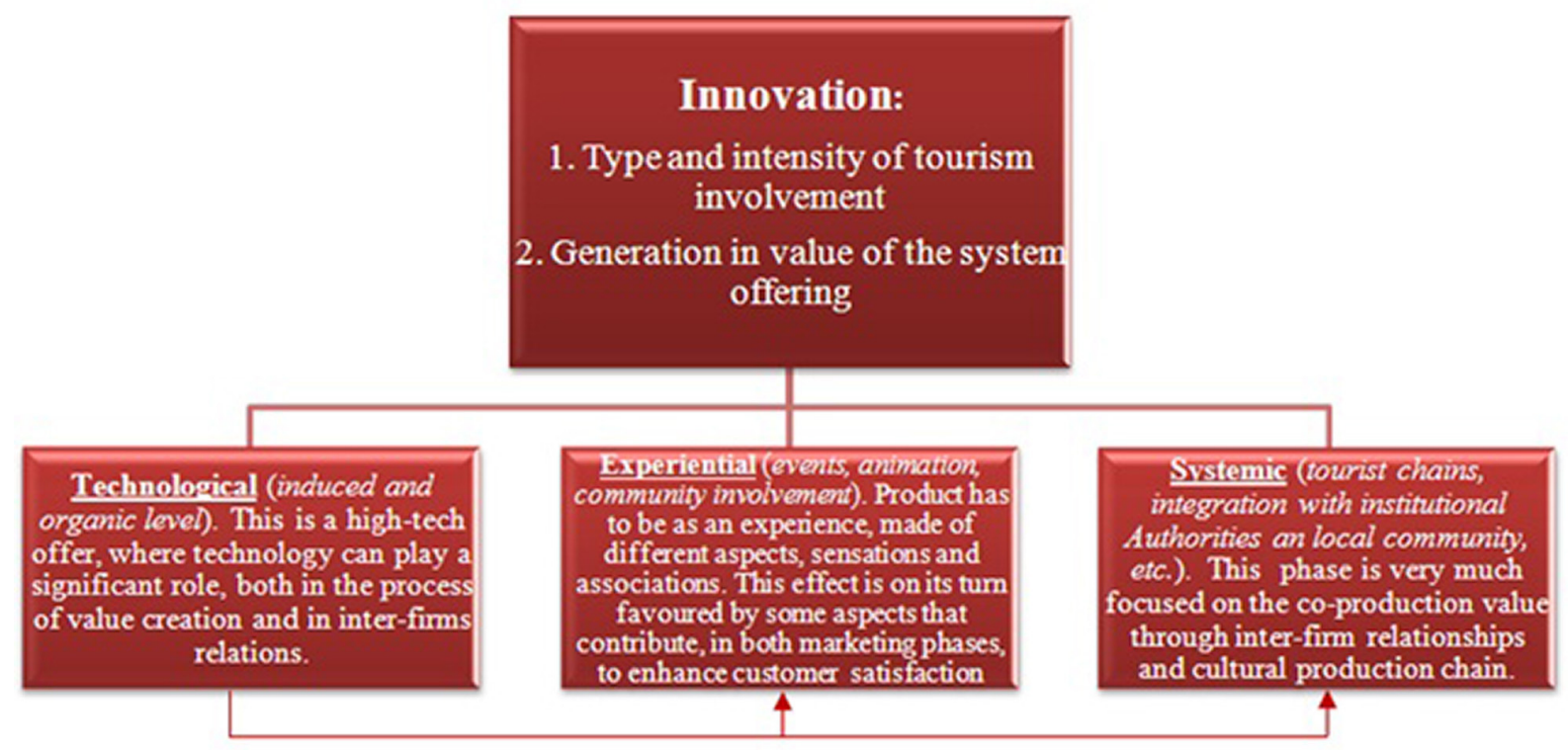

Figure 3. Innovation in cultural firms

Some examples could be the organization of cultural activities, events that involve the customer in education and entertaining activities (so called edu-tainment), in which the costumer is not only addressee of information, but becomes an active factor in the learning process (for example through his/her involvement in lab activities, the reading and commenting passages or participation to special meetings, etc.). By implementing the innovative factors in management of cultural firms, it is possible to achieve the experiential process if the customer becomes actor and user (Carù \& Cota, 2003). With specific reference to cultural firms, these have known a profound evolution, according to which, in the first phase, ICT has played a relevant role, with a more specific implementation at the induced level of the marketing process (that is the phase in which customer's attention has to be caught even though through an interactive process). The second phase has been characterized by a grater attention to the experiential component (Rinallo, Borghini \& Golfetto, 2010), that is a set of knowledge, emotions and new sensations. From this point of view, in this phase, ICT has been mainly applied with reference to the visit, through videos with the history of the site, computer interactive rooms with key people of the history, etc. The last factor mainly refers to cultural firm's capacity of interacting with other key actors in the sector and in the destination, in cultural and tourist terms. In this direction, starting from the model used by Della Corte et al (2009), we propose an extension of that model which focuses on the more traditional and innovative factors. The basic message, however, is that innovative factors are by no means more important than traditional ones: it is important to verify the most appropriate mix of factors beyond which the most strategic resources (sources of sustainable competitive advantage, according to RBT) and the role of customer are influenced by the complex set of relations the firm manages and controls. 


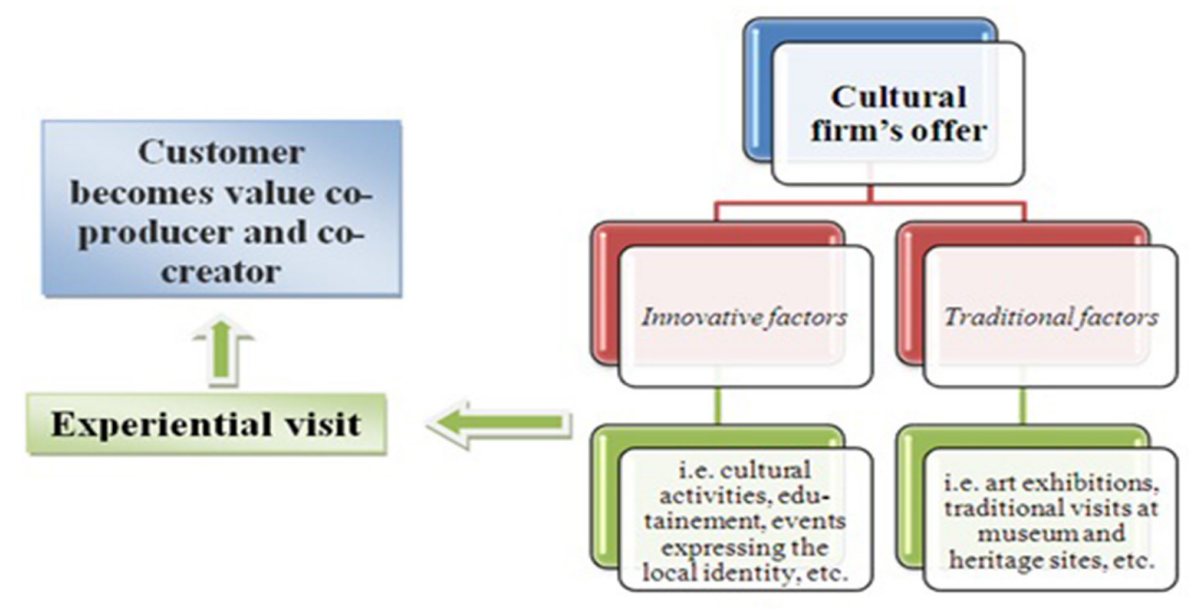

Figure 4. New business model for cultural firms

In summary, our theoretical approach proposes a combined use of internal and external factors: by a side, cultural firms must interact with both other firms (external network) and customers (internal resources) and, by the other side, they must propose innovative factors because through them it is possible to turn the customer into a strategic resource.

Compared to the literature, our methodological approach is very innovative. It proposes a strategy frameworkthat can easily and fruitfully be implemented both in public and private firms. Furthermore, our interdisciplinary approach seems interesting for both researchers and managers, being a valid instrument for the decision-making. Through our model, we think that it is possible to achieve a more complex vision of value creation process. In our opinion, the interaction and the synergy between the internal/external network (i.e. including customers and trade actors) and the internal/external resources (i.e. territorial factors and firm specific resources) determine it. Therefore, for cultural firms, one of the most important challenge is being international (fundamental aspect in a hypercompetitive and global context) without losing but even evaluating the identity of their territory as a key to competitive advantage.

\section{Methods}

In order to control our research questions, we decided to adopt the case study analysis (Sbrana\& Gandolfo, 2010). Data have been collected (Eisenhardt, 1989) through a complex method based on both ad hoc questionnaires (based on two hours telephone interviews to managers) and on-line information collection. Even though the case study analysis is often used in the empirical research (Allen, 1965; Allison, 1971; Dahl, 1960; Johnson, 1983; Kaufman, 1960; Lazarsfeld, Berelson\&Gaudet, 1948; Lijphart, 1968; Pressman \&Wildavsky 1973), it has not yet had a univocal and shared definition. In fact, (Gerring, 2004) "to refer to a work as a case study might mean:

1) that its method is qualitative, small-N (Yin, 1994);

2) that the research is ethno-graphic, clinical, participant-observation, or otherwise "in the field" (Yin, 1994);

3) that the research is characterized by process-tracing (George \& Bennett 2004);

4) that the research investigates the properties of a single case (Campbell \&Stanley 1963; Eckstein, 1992); or

5) that (Campbell \&Stanley 1963; Eckstein, 1992) the research investigates a single phenomenon, instance, or example (the most common us-age)".

In our opinion, each of these definitions seems to catch only some (striking) aspects of this methodology, causing a strong confusion about its exhaustive meaning and so about its feasibility in different fields of empirical research. Therefore, instead of proposing further definitions, we try to understand the heuristic potentialities of this methodology in our research. In general, case study analysis is (Yin, 1994) "an embedded design, that is, multiple levels of analysis within a single study" or, maybe more precisely in our case, (Gerring, 2004) "an intensive study of a single unit for the purpose of understanding a larger class of (similar) units." In fact, differently from others, this definition stigmatizes three fundamental aspects of this methodology: 1) it is not able to statistically verify the existence of statistical connection between items; 2) it cannot be used to study large samples; and so 3) the researcher has to choose one or more units conceived as significant on the basis of 
selected criteria. In our case, the third aspect constitutes the strength of this methodology, commanded by the need of studying few precise firms that in our case are three Italian museums: the MAXXI, the CAM and the Madre Museum. These are all focused a modern and contemporary arts, with more innovative schemes of offer that seem to guarantee a careful and exhaustive overview about the declination of different competitive schemes. Such cultural firms have heavily enriched their offer (proposing dance and theatrical shows, educational activities for adults and children, etc.) over time. Some activities imply a different conception/perception of the customer, here conceived as value co-producer and co-creator. By case study analysis, some interesting comparisons have been made (Table 1).

Table 1 . Annual visitors' number $(-1=$ smaller than the normal one; $1=$ equal to the normal one; $2=$ greater than the normal one; $0=$ missing activity)

\begin{tabular}{lccc}
\hline & \multicolumn{3}{c}{ TOURISTS FLOWS } \\
\cline { 2 - 4 } Innovative activities & CAM & MAXXI & MADRE \\
\cline { 2 - 4 } Children education & 2 & 1 & 2 \\
Adults education & 2 & 1 & 2 \\
Lessons & 0 & 1 & 2 \\
Shows (dance, theatre, concert, etc.) & 1 & 2 & 2 \\
\hline
\end{tabular}

Source: our reworking

According to the table, we can immediately see that

1) For CAM, the touristic flow is greater than the normal level for educational activities and equal to the normal one for entertainment shows (in the analysis, the normal visitors' number is the annual number of tourists that visit the museum for art exhibitions and other not innovative activities - in the meaning previously specified);

2) For MAXXI, we have an opposite trend because the more attractive activity is the second one (i.e. dance, theatre, concerts, etc.);

3) The Madre case is completely different because all innovative activities are able to guarantee a greater flow level than the normal one. This result does not mean that, for those museums, certain activities are considered more important than others, but only that those activities are able to generate, in the relative firms, different levels of flows. In our opinion, this outcome is strictly connected with the firms' customer conception/perception (table 2).

Table 2. Firms' customer conception/perception $(0=$ no; $1=$ yes $)$

\begin{tabular}{lccc}
\hline The customer is & CAM & MAXXI & MADRE \\
\cline { 2 - 5 } Simple user & 0 & 1 & 1 \\
Value co-producer & 1 & 0 & 0 \\
Value co-creator & 0 & 0 & 0 \\
\hline
\end{tabular}

Source: our reworking

No-one declares to conceive the customer as value co-creator and only the CAM seems to see the client as value co-producer. Indeed, CAM proposes a very innovative offer with the "adoption" of its works of art: its consumers can choose among 100 works of art and take them to their home/office/etc.. Customer therefore becomes a real patron and so a real value co-producer. The initiatives of a more interactive relationship between the artist and the visitors are a real tool to favor all generations approach and comprehension of contemporary and modern arts. In any case, in our opinion, it does not mean that MAXXI really conceives its customer only as a simple user: MAXXI museum is one of the most pro-active cultural firms in defining an enlarged offer and its performance results (in terms of flows' level, see Table 2) seems to highlight the innovative firm's customer perception. Madre Museum management seems not to be able to perceive its customer as co-producer or co-creator. If, however, we look at the market, Madre and Maxxi seem to have a wide business view (tab. 3). 
Table 3. Why did you enlarge your cultural offer?

\begin{tabular}{llcc}
\cline { 2 - 3 } & $\begin{array}{c}\text { Changing } \\
\text { demand }\end{array}$ & $\begin{array}{c}\text { There are no } \\
\text { similar offers }\end{array}$ & Both of them \\
\hline $\begin{array}{l}\text { Simpler user } \\
\text { Value co-producer } \\
\text { Value co-creator }\end{array}$ & MAXXI & MADRE \\
& & CAM \\
\hline
\end{tabular}

Source: our reworking

In fact, MAXXI museum's management turns out to be able to capture the deep and significant changes in demand. Madre museum seems to be able to better foresee demand variations, proposing a rich and enlarged offer. However, the three cases do not show a clear vision of customer as co-producer thus having an "unused" value that is relevant hint for both schedules and decision makers.

CAM museum, even if it is a smaller organization, appears concentrated an innovation in its offer, as function of demand's need in terms of co-production.

On the basis of the first results, the case study approach proves to be the more appropriate methodological choice: in fact, the analysis of single questions suggests interesting observations, but is not able to capture the overall complexity of the units of analysis. Therefore, the firms taken into account can represent paradigmatic realities of our universe. Of course, it cannot guarantee the reliability of obtained results and so any effort to infer findings to the population is impracticable. Nevertheless, respect to the aim of our research, the study of selected firms constitutes a very useful starting-point to control our research questions, and offers interesting insights, for both scholars and managers. The extent of managerial implications ensues from the application of rigorous and iterative process of analysis (Eisenhardt, 1989) that guarantees the possibility of formulating general theories starting from results obtained by applying case study methodology. In fact, the case study analysis imposes a dynamic and iterative perspective, according to which it needs (Eisenhardt, 1989) "to compare systematically the emergent frame with the evidence from each case in order to assess how well or poorly it fits with case data. The central idea is that researchers constantly compare theory and data using a theory that closely fits the data. A close fit is important to build good theory because it takes advantage of the new possible insights from the data and yields an empirically valid theory." In other words, this methodology changes the traditional perspective of analysis imposed by top-down quantitative approach, according to which the researcher formulates his/her research questions and then he/she controls them by applying quantitative tools. In case study analysis, instead, a different knowledge process fulfills (fig. 5 and 6).

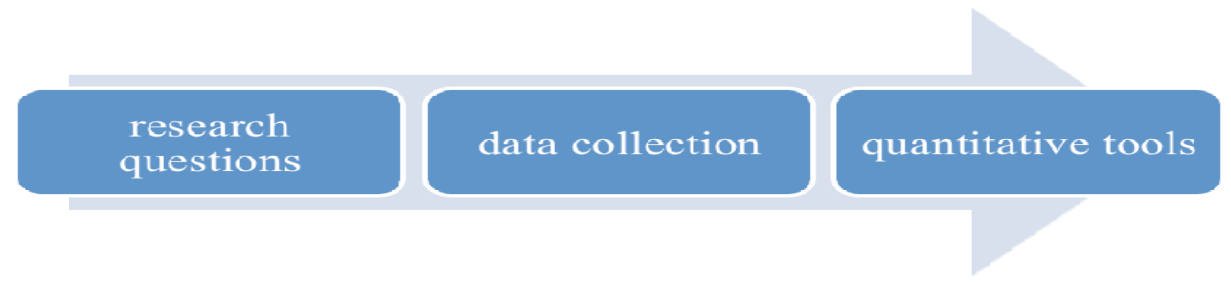

Figure 5. Traditional approach in data analysis Source: our reworking

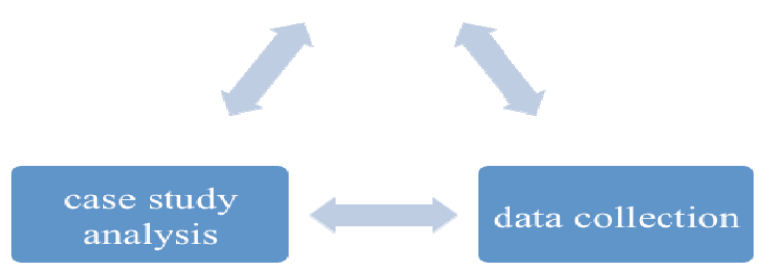

Figure 6. Case study analysis approach

Source: our reworking 
In brief, the implied perspective by the case study methodology seems the more suitable to verify the managerial approach here proposed. In fact, this one is based on an innovative competitive scheme. Therefore, a dynamic and "dialogical" approach, in our case, seems to be more suitable than a rigid top-down perspective.

\section{Findings: Some Empirical Evidence on MADRE, CAM and MAXXI Foundation}

In order to understand the change of the museum management in recent years, this study analyzes three of representative cases of modern and contemporary arts: the MADRE Museum in Naples, the CAM (Contemporary Art Museum) in Casoria near Naples, the MAXXI foundation in Rome, comparing the most innovative approaches characterizing them.

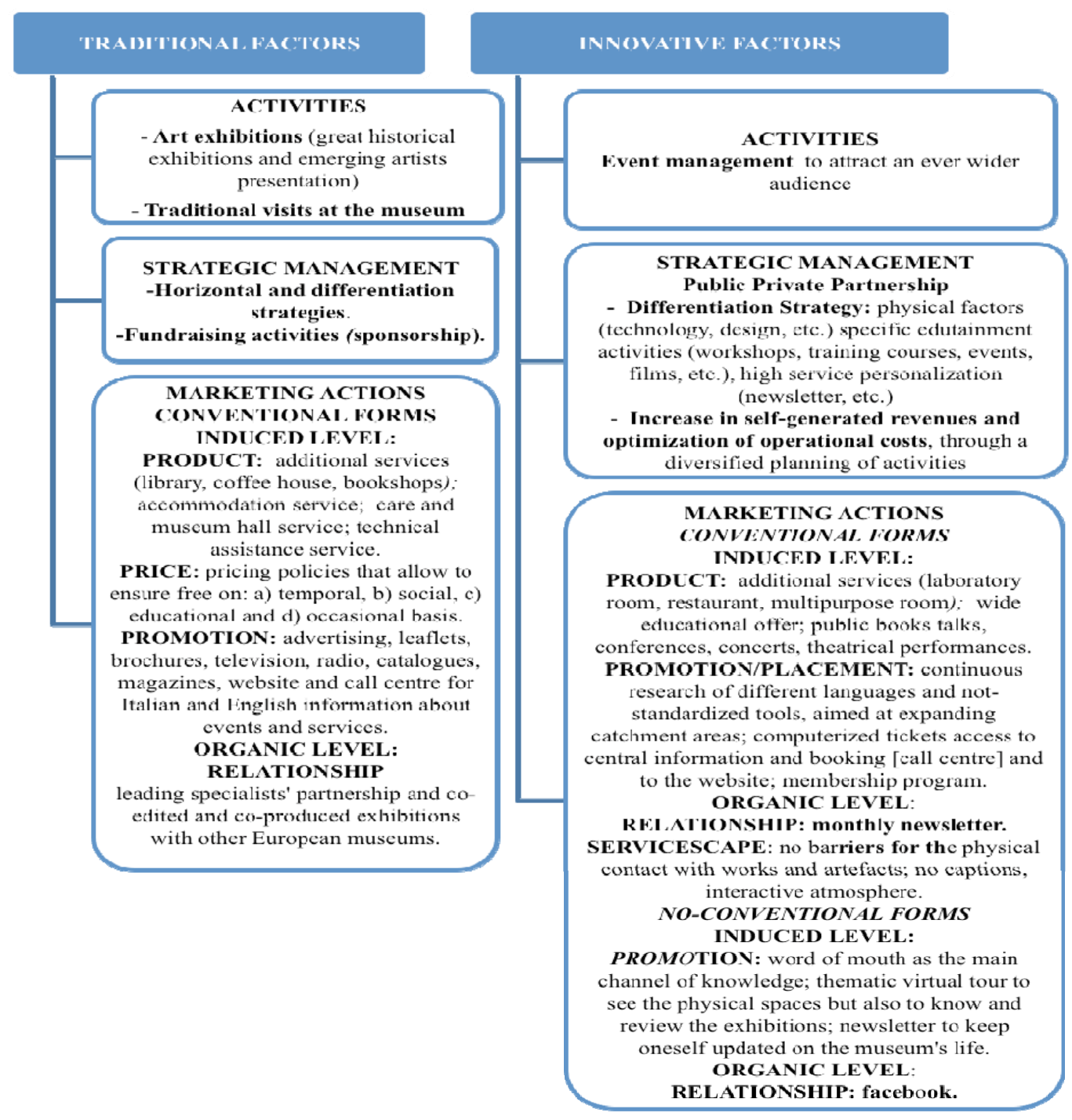

Figure 7. MADRE's traditional and innovative factors

These museums have different characteristics and life cycles, although they are all well known at both national and international, especially for the variety of services they provide. Our analysis emphasizes various factors that characterize these firms management as well as the strategic resources that sustain their competitive advantage in the international context. Figure 7 describes Madre's offer, distinguishing between traditional and innovative factors. Among the traditional ones, we find art exhibitions of known or emerging artists and the museum visits that typically shape this kind of entertainment. MADRE's exposition policy alternates great historical exhibitions and emerging experiences keeping a wide space for the temporary shows. As regards the most innovative approaches of a museum offer, event management is a way to attract an ever wider public, improving the 
auto-generated profits and optimizing the operative costs. In strategic management terms, among the traditional approaches, there are horizontal integration strategies, with which the museum management aims at entering in the current market to increase visitors' flows, through a differentiation of activities. As regards more innovative strategies, instead, a series of factors comes out: first, MADRE has public-private partnership governance (PPP) with twelve private companies. This form of governance, with the consequent fundraising scheme, mainly based on sponsorships, seems to be innovative. Finally, the innovative strategies include partnerships and co-operations as strategic resources for the competitiveness into the museum sector. Co-created and co-produced exhibitions are carried out with other European museum institutions. As regards the main marketing activities, at induced level, the study emphasizes that the product is characterized by additional services provided to the visitors in order to assure them a pleasant visit (library, cafeteria, bookshop), within a wider set of services (accommodation, care, museum hall and technical services). In this case study, there are more innovative additional services, such as the laboratory room, the restaurant, and the multipurpose room. The "traditional" promotional policy of MADRE takes place through advertising, leaflets, brochures, TV, radio, catalogues, reviews, internet and call centre. The common traditional promotions includes: the territorial distribution of materials hand to hand; newsletter sending to e-mailing consumer, targets, trade and schools; outbound campaigns to fidelity targets; educational tours aimed at presenting museum spaces, events and educational activities to teachers, schools and actors in the sector. The membership represents another way to promote and communicate since it aims at creating a museum supporters community through the purchase of a MADRECard, which gives visitors special benefits and privileges. The most innovative promotional approach is linked to the not-conventional forms: the word of mouth is the main source of knowledge for the $40 \%$ of the public. The website has a strategic function in promoting, communicating, and informing because it is organized as a sort of virtual museum, in which the exhibition events' documentation is very relevant. The placement presents many innovative factors, thanks to a constant research of different instruments; the MADRE's box office delivers both tickets and advance sales through electronic prints. Finally, with reference to the marketing policies, at an organic level, the servicescape is very important because it represents the visitors' first impression and influences his cultural firm considerations. The absence of barriers, which allows the physical contact with works and artefacts, is a differentiation factor. In terms of relationship, MADRE cooperates with specialists and other museum institutions allowing having many benefits both on offer and on promotional levels thus assuring improvement in reputation. Moreover, the museum provides fidelity-cards. Quality and productivity are very important: the services are marked by high quality thanks to the human resources, which contribute to improve visitors' satisfaction through their presence and courtesy. According to this case analysis and the strategic studies, we can use RBT approach in SDL perspective in order to understand which MADRE's resources allow to conceive and implement strategies able to improve the museum performance in terms of efficiency and efficacy, being source of competitive advantage. Among the main strategic resources, we can find

1) the museum's huge artistic and cultural patrimony; the MADRE holds works of very famous international artists linked to the territory, which allow to gain sustainable competitive advantage because the resources are valuable, rare, costly to duplicate and exploited by the organization;

2) human resources' competencies and skills: a young management, enthusiast of carrying out such activities, who represents a valuable and rare resource, costly to imitate and so able to generate a sustainable competitive advantage;

3) the event management; thanks to it, the museum is able to attract a public with different needs. This resource is able to generate a temporary competitive advantage. In fact, it is a valuable and rare resource but not costly to imitate from the competitors;

4) the fundraising; this resource is valuable and rare but not costly to imitate because it can be replaced with other financing forms as the gifts. For this reason, it only generates temporary competitive advantage;

5) partnerships with other institutions, which give a strong temporary competitive advantage because they are valuable, rare, not costly to imitate and each organized.

Figure 7 sum up the MAXXI FOUNDATION in Rome. The MAXXI Foundation is a public museum. The museum intends not only to be a container for the exhibition of the works of art of our century, but also a place for cultural innovation and the overlapping of languages, a laboratory for artistic experimentation, a machine for the production of aesthetic materials of our time. MAXXI aims to be a centre of excellence, an interactive hub in which the most diverse forms of expression, productivity and creation may converge, combine and reproduce. Figure 7 describes the museum distinguishing between traditional and innovative factors marking the MAXXI's offer. Among the traditional ones, we can find 
1) MAXXI Art intends to continue to be an interpreter of and an exhibition of diverse voices, aware that contemporaneity has varied forms with roots in the 20th century and even further back. The museum therefore focuses on the promotion of young art and their valorization. We may consider as its masters and movements that were active in the 20th century but still dialogue in the 21st. MAXXI Art stands as a contemporary museum set within unconventional architecture, a point of departure for a new museographic experience that breaks with the past. With its surface area of 13,500 square meters and its permanent collection, MAXXI Art represents an experimental space that as well as its own collection and exhibition program proposes an interdisciplinary cultural offering that naturally includes art but also explores theatre, dance, music, fashion, graphics, films and advertising. The museum's activities are well suited to its flow structure that makes possible a reading that is not conditioned by the spaces and the works, a unique experience for visitors who are invited to explore a temporal and spatial contemporaneity composed of events, exhibitions and performances;

2) MAXXI Architecture is the first national museum of architecture established in Italy, its roots in the Italian cultural and territorial context defining its identity. Two distinct spirits coexist in the museum, one devoted to the historical architecture of the 20th Century and the other responding current issues. Therefore, a museum that is both historical and contemporary; one in which past and present intersect, adopting forms and methods suitable for developing a particular knowledge path and analyzing trends and personalities, cultural models and social behaviors. The MAXXI Architecture Collections comprise all those artifacts and documents that represent the material and conceptual complexity of architecture through its evolutionary processes: from design idea to physical realization, through to its use and insertion in the physical and cultural context. The most innovative approaches of this museum offer are the events. This strategic choice depends on: 1) market changes (a customer who asks a more and more integrated and complex offer); 2) a different way to attract an ever wider public, improving the auto-generated profits and optimizing the operative costs. Special private events (gala dinner, cocktails, cinematographic musical comedies events, conference, meeting, formative publishing presentations, course, and educational workshops for children and, for the future, theatre events) are expression of an innovative concept in strategic management that sees the events organization as complementary and still cultural activity, of support to the classic museum management like simple container of art works.

3) Finally, the innovative strategies include: offer widening; continuous attention to service quality; collaboration with local tourist offer's main actors (for example, MAXXI's clients can benefit particular rates in some hotels in Rome); territorial involvement. In particular, in terms of the widening of its offer and the acquisition of resources and specific competences, the Maxxi means to increase at least $15 \%$ own number of visitors. With reference to SDL theory, Maxxi management however sees customer as a simple client of the museum, without involvement in terms of product creation (only few initiatives like the choice of the name of the new restaurant in the Maxxi). According to this case analysis and the strategic studies, we can use the RBT approach in a SDL perspective in order to understand which Maxxi's resources allow to conceive and implement strategies able to improve the museum performance in terms of efficiency and efficacy, being source of competitive advantage.

Among the principal strategic resources, we can find:

1) the museum's huge artistic and cultural patrimony; the resources are valuable, rare, costly to duplicate and exploited by the organization;

2) human resources' competencies and skills: a management enthusiast for the carried activities out, thus representing a valuable and rare resource, costly to imitate and so able to generate a sustainable competitive advantage;

3) the event management; thanks to it, the museum is able to attract a public with different needs and requirements. This resource is able to generate a temporary competitive advantage. In fact, it is a valuable and rare resource but not costly to imitate from the competitors.

As regards the main marketing activities, at an induced level, the study emphasizes that the product is characterized by additional services (Mauri, 2010) provided to the visitors in order to assure them a pleasant visit (cafeteria, bookshop and restaurant), according to the other service. In this case study, there are many more innovative additional services. The Education Department offers a program of educational activities, aimed at different audiences by age and expectations, from the amateur to the experts, in order to provide the tools for an active and participatory view of contemporary themes. The most innovative promotional approach is the one linked to the non-conventional forms: the web site has a strategic function in promoting, communicating, and 
informing because it is organized to give a series of very detailed information on all activities and services provided by Museum. It is possible to purchase tickets for events and visits to the Museum Maxxi, with the choice to pick up tickets one hour before at the ticket office or by sending the tickets by courier. Finally, with reference to the marketing policies, at an organic level, the servicescape is very important because it represents the visitor's first impression and influences his cultural firm considerations. In terms of relationship, the Maxxi cooperates with specialists and other museum institutions allowing getting many benefits both on the offer side and on the promotional side as well as assuring improvement in reputation. Moreover, the membership represents another way to promote and communicate because it aims at creating a museum supporters community through the purchase of a MAXXI Cards (MY MAXXI and I LIVE MAXXI), which gives visitors special benefits and privileges. This membership means supporting one of the most fascinating museums in the world and the possibility to take advantage of exclusive benefits.

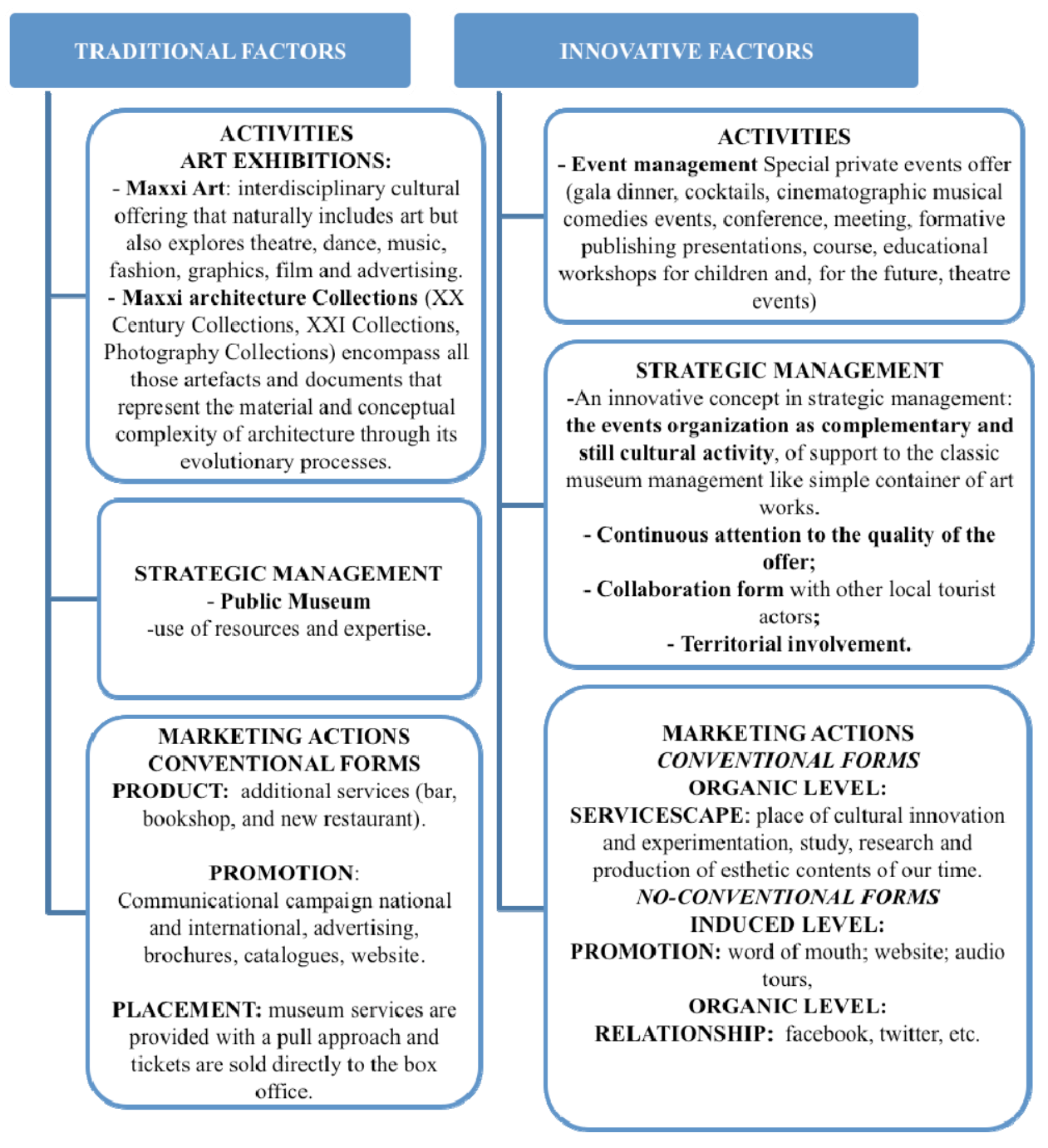

Figure 8. MAXXI Foundation and its innovative factors

Continuing with the empirical analysis, we chose to analyze a case (Figure 8) that, in recent years, is having huge success in terms of visitors both national and international: the CAM - Casoria Contemporary Art Museum. It is a Private Museum (i.e. not financially supported by public, but purely by private sponsors), set up in 2005 with the aim to become a cultural hub, an experimental laboratory, but also a cultural landmark, vibrant and exciting for everyone and not a static place, for an universal and contemporary art open to everything. With this operation, they aimed to create a village of forms, a sort of ideal city in which these arts live together in harmony, allowing them to express their differences. The Figure 8 describes the museum distinguishing between 
traditional and innovative factors of the CAM's offer. Among the traditional things, we find 3,000 square meters of permanent exhibition of approximately 1000 pieces of contemporary art of painting, sculpture, photography, video, multimedia art, and installations by leading artists from around the world. It boasts one of the largest European collections of Oriental art and multimedia art and the most comprehensive collection of works by contemporary artists from Naples after World War II to today. About the innovative activities, the research shows the organization of activities that make the museum a place where culture and research are produced, where there is didactic program for students and where are treasure organized hunts. So, CAM becomes a mysterious place where you hide a great treasure and with the help of scattered clues and support of educators, you find the "Great Treasure" of the Museum. This approach stimulates a unique experience where you see the creativity, knowing and practicing the current aesthetic complexity. In order to make contemporary art clear and understandable to all those who wish to broaden their horizons, they organize regular workshops where artists are invited thus contributing to the interaction between the artist and the visitor. The CAM performs promotional activity, exhibitions, cataloging, preservation of books on contemporary art, and both an activity devoted to the making of traveling exhibitions and events in collaboration with leading museums of contemporary art worldwide. Therefore, the activities of CAM, which are among the factors of innovation, are:

1) CAM EDUCATIONAL; with the Office of Teaching, which has the main objective of providing the necessary tools for a broad and accurate understanding of the historical-artistic and techniques of contemporary art;

2) CAM ARCHIVE; this organization invite all the operators (artists, critics, curators, galleries, editors, magazine in order to cooperate to the creation of a Continuously-updated International Centre of Documentation for all the operators;

3) CAM THEATER; With this project the CAM hosts a series of experimental theater events and art performances.

In terms of competitive strategic decisions, the CAM has triggered a series of activities to be more competitive in this market: first, the combination of the cultural product with the organization of events. This choice, in strategic terms, has been motivated by the lack of a cultural offer comparable in the territory and the desire to mark fixed meeting for target of people that like varied cultural offerings. In addition, the company has implemented a series of strategic choices both through innovative intervention at the strategic and operational level, specifically with agreements and alliances with other industry players, horizontally in the chain (with other museums), and both through the acquisition of resources and expertise. In the future, to achieve greater competitiveness, the company will further invest in technology and multimedia upgrades and in structural growth. With reference to the theory of SDL, this museum actually sees the customer as co-producer of the museum offer, so that the cultural evolution goes hand in hand with social and technological transformations. In particular, the choice of a direct involvement towards the customer is given by two specific actions:

1) the possibility of adopting a work of art in the CAM only for $1 €$ per day, allowing the user / patron to find set out its name in the caption of the work: the winning idea is the one of associate the private patronage to culture and art places. You can choose from all the works from the permanent collection of CAM during the period of adoption ( 2 months minimum) the user / patron will be entitled to free entry in the museum and to the reduction of admission for friends and relatives;

2) the possibility of adopting a work of art in the CAM only for $2 €$ per day and show it at home or in your company: the works of art can be sold in "Adoption" for some time to private citizens, public and private companies, banks, local shops to facilitate the needs of preparations for special events. With the adoption the user will have the opportunity 'to periodically replace the works, changing them to depending the taste and needs. Rent a work of art is the best way to periodically renew their environments: home, office, shop. This idea has been conceived considering that, for special events, the adoption of a work of art becomes a tool of communication, innovation, and a tangible sign of sensitivity to the art and culture world. In terms of marketing decisions, CAM, like all cultural backgrounds, currently has the need to support their cultural and artistic offer with a method and a communication that involves the largest possible number of users, both repeaters and first timers, to approach them more and more in the cultural and artistic world. 


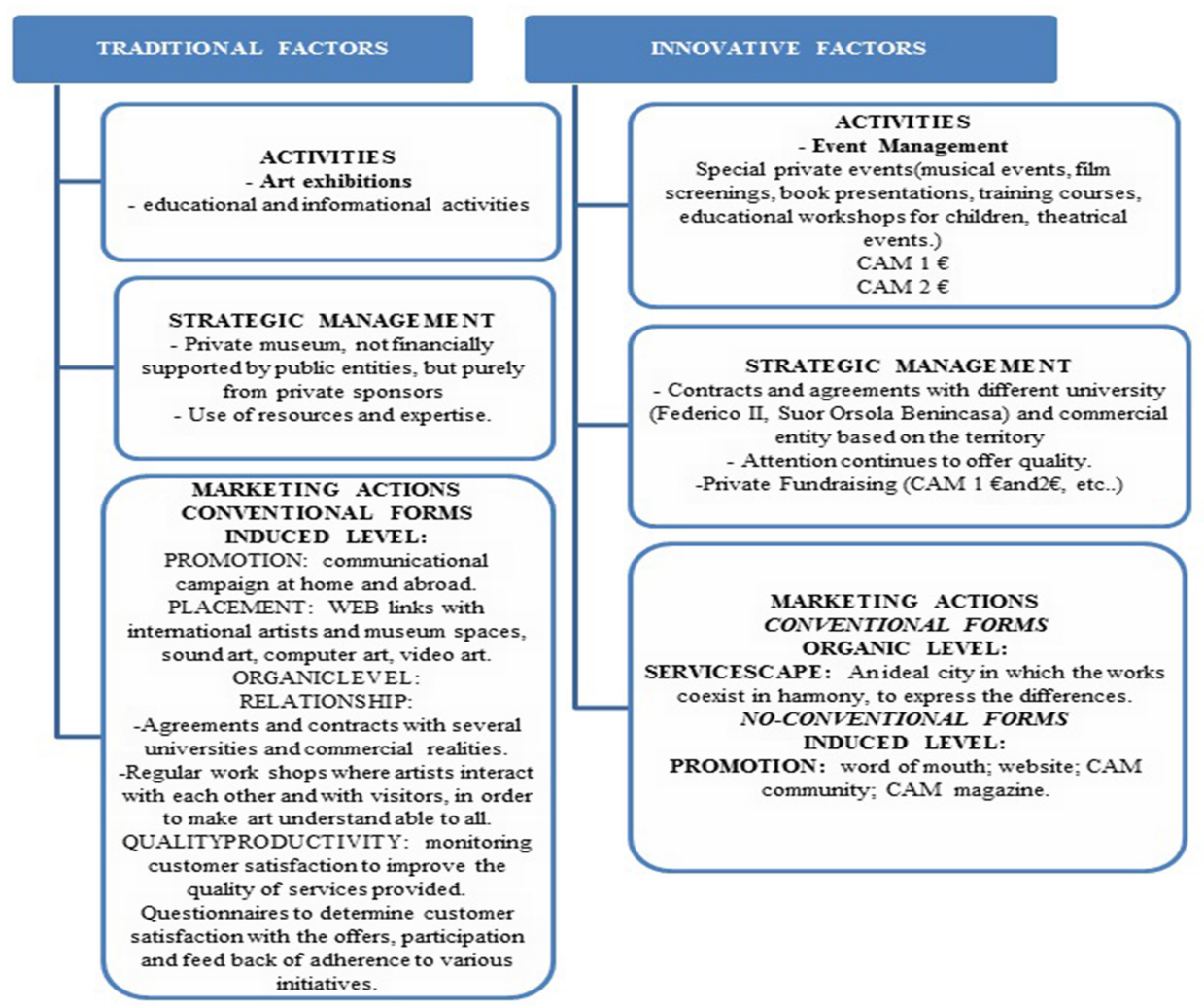

Figure 9. CAM and its innovative factors

The cultural competition, institutional and private, forces the museum to present the public with innovative and exciting ideas and proposals. Other than the presentation of the museum products, CAM offers educational programs in the museum, which will be integrated with the theoretical education through a direct approach to the works of art. This contact raises the interest of children and their teachers that are participating in great numbers. Curiosity and the novelty are attraction for a large number of visitors. The CAM is developing an ongoing marketing strategy that involves structures and communications companies who, through promotions or special offers, bring the users in the Museum. The CAM has joined and developed conventions and agreements with several commercial realities on the Italian territory, to fit into those channels of promotion and communication that have strong commercial characteristics, enriching them with a socio-cultural offer that adds value to any business proposal. Many companies want to insert the CAM into their communications networks and trade promotion, others are cases in which there is a need for "institutional" to create networks and partnerships, with a firm that in itself has both national and international contacts in the cultural world. They are consequential the inquiries and statistics of customer satisfaction to the submitted offers, with feedback of involvement and adhesion to the various initiatives, since even the cultural offerings are now evaluated in terms of payback and image that involved partners have to study, starting on or increasing their cultural marketing strategies. From here, questionnaires and evaluation sheets, both internal and external, are in turn processed to have a statement of how the cultural organization is proceeding in marketing terms. The CAM should relate to this type of marketing strategies, since, as a private entity is not subsidized by local authorities, owes its survival to its ability to enhance and strengthen its brand in the artistic circuit of relations both international and national, to ensure those funds or sponsorship for an support of its artistic, cultural and social programs.

\section{Discussion and Conclusions}

Starting by their marketing behaviors, it is possible to compare the three examined cases especially with reference to three themes: the type of governance, the strategic decisions and the implemented marketing strategies, both with respect to the more forms traditional (conventional forms) and to the more innovative ones (unconventional). 
Table 4. MADRE, MAXXI and CAM's innovative parameters

\begin{tabular}{|c|c|c|c|}
\hline & GOVERNANCE & $\begin{array}{l}\text { STRATEGIC } \\
\text { MANAGEMENT }\end{array}$ & $\begin{array}{l}\text { MARKETING } \\
\text { CHOICES } \\
\end{array}$ \\
\hline MADRE & $\begin{array}{l}\text { PUBLIC-PRIVATE } \\
\text { PARTNERSHIP } \\
\text { GOVERNANCE (PPP) }\end{array}$ & $\begin{array}{l}\text { Event Management; } \\
\text { Public Private } \\
\text { Partenership }\end{array}$ & $\begin{array}{l}\text { No conventional forms } \\
\text { (word of mouth, virtual } \\
\text { museum visit); } \\
\text { Placement: electronic } \\
\text { ticket sale }\end{array}$ \\
\hline $\begin{array}{l}\text { MAXXI } \\
\text { FOUNDATION }\end{array}$ & $\begin{array}{l}\text { PUBLIC } \\
\text { GOVERNANCE }\end{array}$ & $\begin{array}{l}\text { Event Management; } \\
\text { Offer widening; } \\
\text { Continuous attention to } \\
\text { the quality of the offer; } \\
\text { Collaboration form with } \\
\text { other local tourist actors; } \\
\text { Territorial involvement }\end{array}$ & $\begin{array}{l}\text { No conventional forms } \\
\text { (word of mouth, virtual } \\
\text { facebook, twitter, } \\
\text { website, audio tours); } \\
\text { Advanced technologies }\end{array}$ \\
\hline CAM & $\begin{array}{l}\text { PRIVATE } \\
\text { GOVERNANCE }\end{array}$ & $\begin{array}{l}\text { Internalization strategy; } \\
\text { Event Management; } \\
\text { Client like co-productor } \\
\text { of museum offer; } \\
\text { Collaboration form with } \\
\text { other local tourist actors; } \\
\text { The customer becomes a } \\
\text { patron and can, paying, } \\
\text { adopt a work of art }\end{array}$ & $\begin{array}{l}\text { No conventional forms } \\
\text { (word of mouth, website, } \\
\text { CAM Community, CAM } \\
\text { Magazine); } \\
\text { Advanced technologies }\end{array}$ \\
\hline
\end{tabular}

This paper highlights a very important issue in an emerging sector: that of the cultural firms. As it can be drawn, there are important implications, both theoretical and managerial. As regards the first aspect, the new key of innovation for these firms is the development of interactive activities with customers, according to a process where clients are an integral and relevant actor in starting and developing innovative ideas and activities. The museum rather than the heritage site must become "alive" to be successful, to remain impressed in the visitor's head and to be concrete attraction factors for their territories. This confirms other researches (Della Corte et al., 2009), mainly based on the idea that innovation can favor an integrated process of value co-creation among different actors. The so created system adds value to the cultural firm itself, which therefore benefits from common and shared resources. It is important to underline that, even if many aspects of their strategic and marketing approaches reveal a strong interaction with customer, management still seems not to be aware of the strategic relevance of co-production of co-creation processes. Such awareness would, in our opinion, open to horizons and opinions, also in terms of relationships with different stakeholders of the global market.

The research also has some limitations, since it examines Italian museums. In our research, we in fact intend to proceed with an international view, in order to make our results more generalizable. However, the here proposed model and tools can be applied to any cultural firm.

In managerial terms, the research results represent a way to push managers in charge of the leadership of cultural firms towards a highly business and strategic-oriented approach. This, however, pays for the governance systems in various countries, which are also strictly bound to the public rather than private nature of the property. The central issue is that, in spite of the governance configurations, innovative approaches within the fields of strategy and marketing should be adopted. It is therefore necessary to deal with cultural firms and not with cultural sites: from site (here including the museum) to firms, with specific very innovative strategies in an ever-growing global market. Another relevant implication is that in particular modern and contemporary arts museums are different from the historical attractions, rooted and bound to the history of the site. From a certain point of view, they can be considered as "man made" attractions, that could be set anywhere, if management succeeds in exhibiting the most outstanding artists and to manage the museum through the above explained innovative approaches. And we think that, in this innovative process for competitiveness, it is important to connect the cultural firms to territorial factors (Ugolini \& Vigolo, 2010) that represent its identity. Madre museum, for example, is in the heart of the old city of Naples, surrounded by the famous "quartieri spagnoli", where the poor people leave in a very odd but characteristic way (narrow streets, micro-houses, many stuff outside the flat in the street, etc.). The challenge for these organizations is therefore to become artwork containers full of distinctive 
local factors (both in terms of involved artists and of integration with local social and cultural environment). From this point of view, also local Authorities do have to accept and even support the new concept of cultural museum, where the business management and strategy logics are necessary to survive and even to gain competitiveness in the global market. The main problem of such organizations, in fact, is that they depend too much on public control and funds, being therefore subject to public policies often led by financial decisions, especially in times of economic crises and stagnation.

\section{References}

Allen, W. S. (1965). The Nazi Seizure of Power: The Experience of a Single German Town, 1930-1935. New York: Watts.

Allison, G. T. (1971). Essence of Decision: Explaining the Cuban Missile Crisis. Boston: Little, Brown.

Baldassarre, F. (2009). Il museo: organizzazione, gestione, marketing. Franco Angeli, Milano.

Barney, J. B. (1991). Firm resources and sustained competitive advantage. Journal of Management, 17(1), 99-120.

Barney, J. B. (1996). Gaining and Sustaining Competitive Advantage. Addison-Wesley, New York, NY.

Barney, J. B. (2002). Gaining and sustaining competitive advantage (2nd ed.). Prentice Hall, US.

Barney, J. B. (2006). Gaining and sustaining competitive advantage (3rd ed.). Pearson Prentice-Hall, Upper Saddle River, NJ.

Bonetti, A. (2006). Tv in azienda, i top manager creano la rete. Da Enel a Costa Crociere, sempre più gruppi si affidano ai circuiti interni di comunicazione in Corriere della Sera.

Busacca, B., \& Bertoli G. (2009). Customer Value. Soddisfazione, fedeltà, valore. Egea.

Campbell, D. T., \& Stanley, J. (1963). Experimental and Quasi-Experimental Designs for Research. Boston.

Carù, A., \& Cova, B. (2003). Esperienza di consumo e marketing esperienziale: radici diverse e convergenze possibili. Micro \& Macro Marketing, 2, 187-211.

Cohen, W. M., \& Levinthal, D. A. (1990). Absorptive capacity: a new perspective on learning and innovation. Administrative Science Quarterly, 35, 128-52.

Dahl, R. A. (1961). Who Governs? Democracy and Power in an American City. New Haven, CT: Yale University Press.

D'Amico, A. (2011). Typical products in the Experience Economy. In Oczkowska R., \& Mikuła, B. (Eds.), Knowledge - Economy - Society. Challenges of the Contemporary World (pp. 257-263). Cracow: Foundation of the Cracow University of Economics.

Das, T. K., \& Teng, B. (2000). Instabilities of strategic alliances: an internal tensions perspective. Organization Science, 11(1), 77-101.

D'Aveni, R. A. (1994). Hypercompetition: Managing the Dynamics of Strategic Maneuvering. The Free Press, New York, NY.

Della Corte V., \& Sciarelli, M. (2005). Risorse, competenze e vantaggio competitive sostenibile. Carocci Editore. Translation and Adaptation of the book "Gaining and Sustaining Competitive Advantage", Barney J.B., Prentice Hall.

Della Corte, V., Savastano, I., \&Storlazzi, A. (2009). Service innovation in cultural heritages management and valorization. International Journal of Quality and Service Sciences, 1(3), 225-240.

Dyer J., \& Singh, H. (1998). The relational view: cooperative strategy and resources of inter organizational competitive advantage. Academy of Management Review, 23, 660-79.

Eckstein, H. (1992). Case Studies and Theory in Political Science. In Regarding Politics: Essays on Political Theory, Stabil-ity, and Change. Berkeley: University of California Press.

Eisenhardt, K. M. (1989). Building theories from case study research. Academy of Management Review, 14(4), 532-50.

George, A. L., \& Bennett, A. (2004). Case Studies and Theory Development. Cambridge, MA: MIT Press.

Gerring, J. (2004). What Is a Case Study and What Is It Good for? American Political Science Review, 98(2), 341- 354. 
Grönroos, C. (2008). Service-dominant logic revisited: who creates value?

Gulati, R. (1998). Alliance and networks. Strategic Management Journal, 19(4), 293-317.

Gummesson, E. (1995). Relationship Marketing: From 4Ps to 30Rs. Liber-Hermods, Malmo.

Gummesson, E. (2006). Marketing relazionale. Hoepli, Milano.

Gummesson, E. (2007). Exit service marketing - enter service marketing. The journal of Customer Behaviour, $6(2), 113-141$.

Gummesson, E. (2008). Extending the service-dominant logic: from customer centricity to balanced centricity. Journal of the Academy Science, 36(1), 15 - 17.

Hofer, Ch.W., \& Schendel, D. (1978). La formulazione della strategia aziendale. Franco Angeli.

Johnson, C. (1983). MITI and the Japanese Miracle: The Growth of Industrial Policy, 1925-1975. Stanford, CA: Stanford University Press.

Kaufman, H. (1960). The Forest Ranger: A Study in Administrative Behavior. Baltimore: Johns Hopkins University Press.

Lazarsfeld, P. F., Berelson, B., \& Gaudet, H. (1948). The People's Choice: How the Voter Makes Up His Mind in a Presidential Campaign. New York, Columbia Univ. Press.

Lijphart, A. (1968). The Politics of Accommodation: Pluralism and Democracy in the Netherlands. Berkeley: University of California Press.

Mauri, C., \& Cirrincione A. (2006). Shopping nei musei. Emozioni e acquisti nei museum shop. Franco Angeli, Milano.

Michel, S., Brown, W., \& Gallan, S. (2008). An expanded and strategic view of discontinuous innovations: developing a service-dominant logic. Journal of the Academy Marketing Science, 36(1), 54-66.

Nicholls, R. (2010). New directions for customer-to-customer interaction research. Journal of Services Marketing, 24(1), 87 - 97.

Nicholls, R. (2011). Customer-to-customer interaction (CCI): a cross-cultural perspective. International Journal of Contemporary Hospitality Management, 23(2), 209 - 223.

Payne, A. F., Storbacka, K., \& Pennie, F. (2008). Managing the co-creation of value. Journal of the Academy Marketing Science, 36(1), 83 - 96.

Pencarelli, T., \& Forlani, F. (2006). Il marketing dei prodotti tipici nella prospettiva dell'economia delle esperienze. Congresso Internazionale "Le tendenze del Marketing".

Penrose, E. (1959). The theory of the Growth of the Firm. Blackwell, Oxford.

Pine, II B. J., \& Gilmore, J. H. (2000). L'economia delle esperienze. Etas, Milano.

Prahalad, C. K., \& Ramaswamy, V. (2000). Co-opting customer competence. Harvard Business Review, 78(1), $79-87$.

Pressman, J. L., \& Wildavsky, A. (1973). Implementation. Berkeley: University of California Press.

Rinallo, D., Borghini, S., \& Golfetto, F. (2010). Exploring visitor experiences at trade shows. Journal of Business \& Industrial Marketing, 25(4), 249 - 258.

Sbrana, R., \& Gandolfo, A. (2010). Cases in marketing management. Lo studio del marketing tramite il metodo dei casi. Giappichelli, Torino.

Sciarelli, M. (1996). Processo decisionale e valutazione strategica. Cedam.

Solima, L. (1995). L'industria dell'imballaggio. Analisi delle concorrenze in un sistema competitivo intersettoriale. con Rea A., Fariello M., Maggiore G., 1995.

Solima, L. (1998). La gestione imprenditoriale dei musei. Percorsi strategici e competitivi nel settore dei beni culturali. Cedam, Padova.

Tax, S. S., \& Stuart, I. (1997). Designing and implementing new services: the challenges of integrating service systems. Journal of Retailing, 73(1), $105-134$.

Ugolini, M., \& Vigolo, V. (2010). Fattori d'attrattiva e aspettative di qualità nella destinazione turistica: un'indagine nella Provincia di Verona. In Kotler P., Bowen J. T., \& Makens J. C. (Eds.), Marketing del 
turismo (pp. 183-185).

Vargo, S. L., \& Lusch, R. F. (2008a). Service-dominant logic: continuing the evolution. Journal of the Academy of Marketing Science, 36(1), 1-10.

Vargo, S. L., \& Lusch, R. F. (2008b). Why service? Journal of the Academy of Marketing Science, 36(1), 25-38.

Vargo, S. L., \& Lusch, R. F., (2004). Evolving to a new dominant logic for marketing. Journal of Marketing, 68.

Vargo, S. L. (2011). Market systems, stakeholders and value propositions: Toward a service-dominant logic-based theory of the market. European Journal of Marketing, 45(1/2), $217-222$.

Vargo, S. L., Lusch, R. F., \& Morgan, F. W. (2006). Historical perspectives on service-dominant logic. In Lusch, R. F., \& Vargo, S. L. (Eds.), The Service-Dominant Logic of Marketing: Dialog, Debate, and Directions (pp. 29-42). M.E. Sharpe, Armonk, NY.

Yin, R. K. (1994). Case Study Research: Design and Methods. Newbury Park, CA: Sage.

Zahra, S. A., \& George, G. (2002). Absorptive capacity: a review, reconceptualization, and extension. Academy of Management Review, 27(2), 185-203. 